Droniak M. M. Changes of non-specific resistance in patients with postoperative peritonitis with abdominal sepsis. Journal of Education, Health and Sport. 2021;11(03): 231-238. eISSN 2391-8306. DOI http://dx.doi.org/10.12775/JEHS.2021.11.03.022 https://apcz.umk.pl/czasopisma/index.php/JEHS/article/view/JEHS.2021.11.03.022

https://zenodo.org/record/4895321

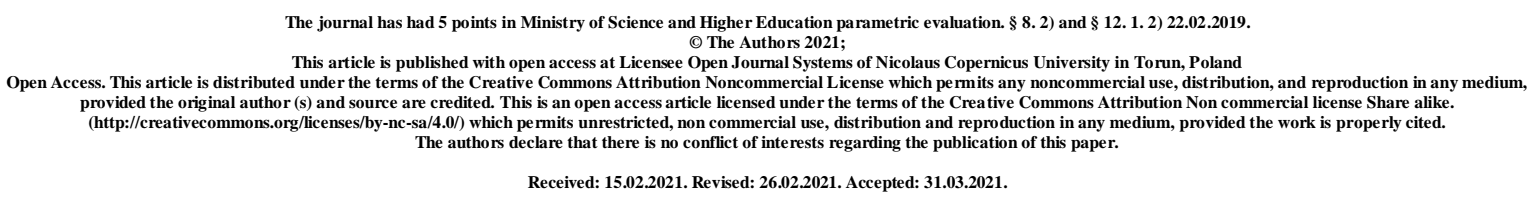

\title{
CHANGES OF NON-SPECIFIC RESISTANCE IN PATIENTS WITH POSTOPERATIVE PERITONITIS WITH ABDOMINAL SEPSIS
}

\author{
M. M. Droniak
}

\section{Ivano-Frankivsk National Medical University}

https://orcid.org/0000-0001-7976-0384

\section{Abstract}

Purpose: to study changes in nonspecific resistance and cytokine regulation in patients with postoperative peritonitis with abdominal sepsis

Materials and methods. The clinic treated 456 patients with postoperative peritonitis who were treated in the surgery department of the municipal non-profit enterprise Regional Clinical Hospital of Ivano-Frankivsk Regional Council in the period from 2000 to 2021. Immunological studies were performed in 66 patients with varying severity of abdominal sepsis and its complications.

Research results and their discussion. In patients with postoperative peritonitis with abdominal sepsis, the phagocytic index during the first week of hospital stay was in control. However, on the 10th-11th day, the phagocytic index decreased 1.6 times, which progressed until the end of the third week of treatment - on the 14th-21st day, the phagocytic index was 2.7 times smaller than the control. The phagocytic count in patients with PP with abdominal sepsis reached maximum values in the first day of the disease $(3 \pm 0.26)$. Later in the treatment process, this figure gradually decreased and on day 14-21 came to normal and amounted to $1.96 \pm 0.10$. The index of completeness of phagocytosis on the first day of the 
disease was1,59 $\pm 0,20$. By 2-3 days it decreased by $1.44 \pm 0.20$ and returned to normal by 14-21 days. Circulating immune complexes were normalized by 5-7 days of the disease.

\section{Key words: Postoperative peritonitis; abdominal sepsis.}

Problem statement and analysis of recent research and publications. Despite new advances in the treatment and prevention of infectious diseases, the incidence of sepsis is increasing. The mortality rate from severe sepsis ranges from $25 \%$ to $70 \%$ with complications of shock and multiorgan failure. The incidence of sepsis and septic shock has increased significantly over the past two decades $[2,6]$. The production of proinflammatory cytokines and chemokines, including tumor necrosis factor-alpha (TNF-??), IL-6 and IL-8, generally triggers favorable innate host immune responses to limit infection and the effects of tissue damage. However, in sepsis, excessive and prolonged production of these cytokines can lead to overstated inflammatory reactions, which is more dangerous than the initial infection $[1,3$, 8]. This occurs in severe sepsis, when excessive production of proinflammatory cytokines causes tissue injury and lethal multiorgan failure. Elevated levels of proinflammatory cytokines are directly correlated with severity and mortality in sepsis. Proinflammatory cytokines play a role in the pathophysiology of sepsis. In fact, these cytokines contribute to the development of the acute phase reaction in fever, leukocytosis, changes in metabolism and activation of complement cascades and blood coagulation. Thus, a steady increase in the levels of these cytokines lead to a variety of pathological reactions that lead to the induction of hypotension and shock. Some studies have been developed to assess the role of cytokine profile measurement in the diagnosis and prognosis of sepsis, but their diagnostic role is controversial $[4,5,9]$.

Purpose: to study changes in nonspecific resistance and cytokine regulation in patients with postoperative peritonitis with abdominal sepsis.

Materials and methods. The clinic treated 456 patients with postoperative peritonitis who were treated in the surgery department of the municipal non-profit enterprise Regional Clinical Hospital of Ivano-Frankivsk Regional Council in the period from 2000 to 2021. General clinical and biochemical studies were conducted in the laboratory of the Department of Biological and Medical Chemistry of Ivano-Frankivsk National Medical University. Patients were divided into three groups depending on the severity of abdominal sepsis: $1 \mathrm{st}$ group - patients with moderate abdominal sepsis, 2nd - with severe abdominal sepsis, 3rd group - patients with extremely severe abdominal sepsis. Immunological studies were performed in 55 patients with 1-3 degrees of severity of abdominal sepsis and its 
complications.

Research results and their discussion. In patients with postoperative peritonitis with moderate abdominal sepsis, the phagocytic index during the first week of hospital stay was in control. However, on the 10th-11th day, the phagocytic index decreased 1.6 times, which progressed until the end of the third week of treatment - on the 14th-21st day, the phagocytic index was 2.7 times smaller than the control.

The phagocytic count in patients with PP with abdominal sepsis reached maximum values in the first day of the disease $(3 \pm 0.26)$. Later in the treatment process, this figure gradually decreased and on 14-21 day came to normal and amounted to $1.96 \pm 0.10$.

The index of completeness of phagocytosis on the first day of the disease was 1,59 \pm 0,20. By 2-3 days it decreased by $1.44 \pm 0.20$ and returned to normal by 14-21 days.

Circulating immune complexes were normalized by 5-7 days of the disease (Table 1).

Thus, in patients with moderate abdominal sepsis, the functional activity of neutrophils is sharply inhibited from the 10th to the 11th day of the post-traumatic period, which is accompanied by a significant increase in the content of circulating immune complexes in the blood. Therefore, the syndrome of endogenous intoxication in patients begins on the 10-11th day after abdominal sepsis without a phase of systemic inflammatory response and lasts until the end of the third week of the postoperative period.

The cellular component of immunity, namely phagocytic activity, has one of the priority places in the implementation of human anti-infective protection, elimination of microbial bodies and the formation of immune memory.

In patients with postoperative peritonitis complicated by abdominal sepsis in a severe condition, the phagocytic index decreased compared with the control by 1.3 times on the first day and was $49.33 \pm 4.20 \%$ with a subsequent increase to $56.17 \pm 3.67$ for $14-21$ days.

The phagocytic count in patients with postoperative peritonitis with abdominal sepsis on the first day of the disease was 1.6 times lower than the control level and reached maximum values on 5-7 days and was $2.79 \pm 0.23$. From 14-21 days it began to gradually normalize.

The index of phagocytosis completion on the fist day was lower than the control level, but on 2-3 days of the disease increased to $1.64 \pm 0.24$ and then gradually decreased to 10-11 days of disease. On 14-21 days, this figure increased to $1.52 \pm 0.17$.

Despite the relative stability of the functional activity of neutrophils, the content of circulating immune complexes in the blood underwent a permanent increase: The concentration of CIC increased compared to the values of almost healthy individuals on the 
first day - by $52 \%$, on the $2-3$ day - by $84.7 \%$, on the 5-7 days - 2.4 times, on the 10-11 days 2.8 times, on the 14-21 days - 3.7 times. (Table 2)

Thus, in patients who were in severe condition due to abdominal sepsis, despite intensive care and relative preservation of functional activity of neutrophils, endogenous intoxication develops from the first day of the postoperative period and increases within three weeks, as evidenced by a permanent increase in blood pressure.

In patients with postoperative peritonitis complicated by abdominal sepsis, who were hospitalized in an extremely serious condition, due to intensive detoxification therapy, the phagocytic index corresponded to the control during the first week of treatment. However, later the rate decreased sharply by 2.9 - 1.8 times, which was accompanied by a decrease in phagocytic number.

The phagocytic count in patients with postoperative peritonitis with abdominal sepsis on the first day of the disease was 1.7 times lower than the control level and reached maximum values at 5-7 days and was $3.11 \pm 0.19$. From $14-21$ days it began to gradually normalize.

The index of phagocytosis completion on the first day was slightly higher than the control level, but by 10-11 days the disease decreased to $1.2 \pm 0.10$, after which there was an increase on 14-21 days of the disease.

Circulating immune complexes from the first day were 1.8 times higher than the control level. Their growth was observed throughout the course of the disease. This indicator reached maximum values on 14-21 days (Table 3).

Thus, the peculiarity of changes in nonspecific resistance in patients with abdominal sepsis, which were in an extremely severe condition, is that intensive detoxification therapy can only temporarily normalize certain parts of phagocytosis, which is not enough to prevent the development of endogenous intoxication - the concentration of CIC in the blood progressively increases throughout the treatment period.

Loss of functionality and reactivity of immune cells in the early stages of peritonitis leads to general immunosuppression in the form of a significant decrease in their absolute number, which is a sign of the development of structural, primarily cellular, defects in the immune system. 
Table 1 - Dynamics of changes in non-specific resistance and blood levels of circulating immune complexes (CIC) in patients with PP complicated by abdominal sepsis of moderate severity (1st group of patients) $(\mathrm{x} \pm \mathrm{Sx})$

\begin{tabular}{|c|c|c|c|c|c|c|}
\hline \multirow[b]{2}{*}{ Studied indicators } & \multirow{2}{*}{$\begin{array}{l}\text { Control } \\
n=35\end{array}$} & \multicolumn{5}{|c|}{ Period of observation } \\
\hline & & $\begin{array}{l}1 \text { day } \\
n=26\end{array}$ & $\begin{array}{c}2-3 \text { day } \\
n=26\end{array}$ & $\begin{array}{c}5-7 \text { day } \\
n=26\end{array}$ & $\begin{array}{c}\text { 10-11 day } \\
n=26\end{array}$ & $\begin{array}{c}\text { 14-21 day } \\
n=26\end{array}$ \\
\hline Phagocytic index, $\%$ & $65,14 \pm 3,48$ & $\begin{array}{c}54,50 \pm 4,22 \\
p>0,05\end{array}$ & $\begin{array}{c}63,65 \pm 3,17 \\
p>0,7\end{array}$ & $\begin{array}{c}64,88 \pm 3,56 \\
p>0,9\end{array}$ & $\begin{array}{c}42,00 \pm 1,67 \\
p<0,001\end{array}$ & $\begin{array}{c}24,08 \pm 1,14 \\
\mathrm{p}<0,001\end{array}$ \\
\hline Phagocytic number & $3,26 \pm 0,12$ & $\begin{array}{c}3,00 \pm 0,26 \\
p>0,3\end{array}$ & $\begin{array}{c}2,95 \pm 0,23 \\
p>0,2\end{array}$ & $\begin{array}{c}2,84 \pm 0,21 \\
p>0,07\end{array}$ & $\begin{array}{c}2,42 \pm 0,20 \\
\mathrm{p}<0,001\end{array}$ & $\begin{array}{l}1,96 \pm 0,10 \\
\mathrm{p}<0,001\end{array}$ \\
\hline $\begin{array}{l}\text { Phagocytosis } \\
\text { completeness index }\end{array}$ & $1,17 \pm 0,06$ & $\begin{array}{c}1,59 \pm 0,20 \\
\mathrm{p}<0,05\end{array}$ & $\begin{array}{c}1,44 \pm 0,20 \\
\mathrm{p}>0,1\end{array}$ & $\begin{array}{c}1,46 \pm 0,19 \\
\mathrm{p}>0,1\end{array}$ & $\begin{array}{c}1,29 \pm 0,17 \\
p>0,4\end{array}$ & $\begin{array}{c}0,65 \pm 0,17 \\
\mathrm{p}<0,01\end{array}$ \\
\hline CIC, u. & $74,98 \pm 2,59$ & $\begin{array}{c}53,60 \pm 4,76 \\
p<0,001\end{array}$ & $\begin{array}{c}93,76 \pm 6,57 \\
p<0,01\end{array}$ & $\begin{array}{c}76,04 \pm 6,95 \\
p>0,8\end{array}$ & $\begin{array}{c}221,60 \pm 9,26 \\
p<0,001\end{array}$ & $\begin{array}{c}189,51 \pm 7,18 \\
p<0,001\end{array}$ \\
\hline
\end{tabular}

$\mathrm{p}$ - the degree of probability of differences in indicators relative to control; $\mathrm{p} 1$ - the degree of probability of differences in indicators relative to the data on the first day of observation; $\mathrm{n}$ - the number of observations. 
Table 2 - Characteristics of nonspecific resistance and content in the blood of circulating immune complexes (CIC) in patients with PP with severe abdominal sepsis (2nd group of patients) $(\mathrm{x} \pm \mathrm{Sx})$

\begin{tabular}{|c|c|c|c|c|c|c|}
\hline \multirow[b]{2}{*}{ Studied indicators } & \multirow{2}{*}{$\begin{array}{l}\text { Control } \\
n=35\end{array}$} & \multicolumn{5}{|c|}{ Period of observation } \\
\hline & & $\begin{array}{l}1 \text { day } \\
n=26\end{array}$ & $\begin{array}{c}2-3 \text { day } \\
n=26\end{array}$ & $\begin{array}{c}5-7 \text { day } \\
n=26\end{array}$ & $\begin{array}{c}\text { 10-11 day } \\
n=26\end{array}$ & $\begin{array}{c}\text { 14-21 day } \\
n=26\end{array}$ \\
\hline Phagocytic index, $\%$ & $65,14 \pm 3,48$ & $\begin{array}{c}49,33 \pm 4,20 \\
\mathrm{p}<0,05\end{array}$ & $\begin{array}{c}55,23 \pm 3,58 \\
p>0,09\end{array}$ & $\begin{array}{c}57,70 \pm 3,25 \\
\mathrm{p}>0,2\end{array}$ & $\begin{array}{c}53,88 \pm 3,69 \\
p>0,05\end{array}$ & $\begin{array}{c}56,17 \pm 3,67 \\
\mathrm{p}>0,1\end{array}$ \\
\hline Phagocytic number & $3,26 \pm 0,12$ & $\begin{array}{c}2,10 \pm 0,17 \\
\mathrm{p}<0,001\end{array}$ & $\begin{array}{c}2,75 \pm 0,25 \\
\mathrm{p}<0,05\end{array}$ & $\begin{array}{c}2,79 \pm 0,23 \\
p>0,05\end{array}$ & $\begin{array}{c}2,60 \pm 0,26 \\
\mathrm{p}<0,02\end{array}$ & $\begin{array}{c}2,39 \pm 0,20 \\
p<0,001\end{array}$ \\
\hline $\begin{array}{c}\text { Phagocytosis } \\
\text { completeness index }\end{array}$ & $1,17 \pm 0,06$ & $\begin{array}{c}1,09 \pm 0,14 \\
p>0,5\end{array}$ & $\begin{array}{c}1,64 \pm 0,24 \\
p<0,02\end{array}$ & $\begin{array}{c}1,31 \pm 0,19 \\
p>0,3\end{array}$ & $\begin{array}{c}1,10 \pm 0,17 \\
p>0,6\end{array}$ & $\begin{array}{c}1,52 \pm 0,17 \\
\mathrm{p}<0,02\end{array}$ \\
\hline CIC, u. & $74,98 \pm 2,59$ & $\begin{array}{c}114,00 \pm 6,60 \\
p<0,001\end{array}$ & $\begin{array}{c}138,47 \pm 5,88 \\
\mathrm{p}<0,001\end{array}$ & $\begin{array}{c}176,65 \pm 7,48 \\
p<0,001\end{array}$ & $\begin{array}{c}210,43 \pm 7,66 \\
p<0,001\end{array}$ & $\begin{array}{c}279,00 \pm 7,88 \\
p<0,001\end{array}$ \\
\hline
\end{tabular}

$\mathrm{p}$ - the degree of probability of differences in indicators relative to control; $\mathrm{n}$ - the number of observations. 
Table 3 - Indicators of nonspecific resistance and content in the blood of circulating immune complexes (CIC) in patients with PP complicated by abdominal sepsis in an extremely serious condition (3rd group) $(\mathrm{x} \pm \mathrm{Sx})$

\begin{tabular}{|c|c|c|c|c|c|c|}
\hline \multirow[b]{2}{*}{ Studied indicators } & \multirow{2}{*}{$\begin{array}{l}\text { Control } \\
n=35\end{array}$} & \multicolumn{5}{|c|}{ Period of observation } \\
\hline & & $\begin{array}{l}1 \text { day } \\
n=26\end{array}$ & $\begin{array}{c}2-3 \text { day } \\
n=26\end{array}$ & $\begin{array}{c}5-7 \text { day } \\
n=26\end{array}$ & $\begin{array}{c}\text { 10-11 day } \\
n=26\end{array}$ & $\begin{array}{c}\text { 14-21 day } \\
n=26\end{array}$ \\
\hline Phagocytic index, $\%$ & $65,14 \pm 3,48$ & $\begin{array}{c}71,70 \pm 2,90 \\
\mathrm{p}>0,2\end{array}$ & $\begin{array}{c}59,25 \pm 2,89 \\
p>0,3\end{array}$ & $\begin{array}{c}62,30 \pm 4,33 \\
\mathrm{p}>0,6\end{array}$ & $\begin{array}{c}22,33 \pm 2,72 \\
\mathrm{p}<0,001\end{array}$ & $\begin{array}{c}36,47 \pm 3,48 \\
p<0,001\end{array}$ \\
\hline Phagocytic number & $3,26 \pm 0,12$ & $\begin{array}{l}1,93 \pm 0,17 \\
\mathrm{p}<0,001\end{array}$ & $\begin{array}{l}2,47 \pm 0,16 \\
\mathrm{p}<0,001\end{array}$ & $\begin{array}{c}3,11 \pm 0,19 \\
p>0,5\end{array}$ & $\begin{array}{c}2,10 \pm 0,14 \\
\mathrm{p}<0,001\end{array}$ & $\begin{array}{l}1,92 \pm 0,20 \\
\mathrm{p}<0,001\end{array}$ \\
\hline $\begin{array}{c}\text { Phagocytosis } \\
\text { completeness index }\end{array}$ & $1,17 \pm 0,06$ & $\begin{array}{c}1,48 \pm 0,20 \\
\mathrm{p}>0,05\end{array}$ & $\begin{array}{c}1,40 \pm 0,16 \\
\mathrm{p}>0,1\end{array}$ & $\begin{array}{c}1,35 \pm 0,10 \\
p>0,1\end{array}$ & $\begin{array}{c}1,20 \pm 0,10 \\
p>0,7\end{array}$ & $\begin{array}{c}1,52 \pm 0,20 \\
p<0,05\end{array}$ \\
\hline CIC, u. & $74,98 \pm 2,59$ & $\begin{array}{c}132,79 \pm 6,28 \\
p<0,001\end{array}$ & $\begin{array}{c}131,50 \pm 6,02 \\
p<0,001\end{array}$ & $\begin{array}{c}211,16 \pm 8,45 \\
p<0,001\end{array}$ & $\begin{array}{c}245,51 \pm 6,28 \\
p<0,001\end{array}$ & $\begin{array}{c}327,68 \pm 9,22 \\
p<0,001\end{array}$ \\
\hline
\end{tabular}

$\mathrm{p}$ - the degree of probability of differences in indicators relative to control; $\mathrm{n}$ - the number of observations. 
Conclusion. Thus, the results of studies on such indicators as phagocytic index, phagocytic number, phagocytosis completion index, circulating immune complexes showed their significant differences between the subgroups studied ( $\mathrm{p}<0,001$ ), indicating their high sensitivity for the diagnosis of postoperative peritonitis, complicated by abdominal sepsis.

\section{References}

1. Muresan MG, Balmo IA, Badea I, Santini A. Abdominal Sepsis: An Update. J Crit Care Med (Targu Mures). 2018; 4(4):120-125.

2. Peake SL, Delaney A, Bailey M, Bellomo R, Cameron PA, Cooper DJ, et al. Goaldirected resuscitation for patients with early septic shock. NEJM. 2014; 371: 1496-506.

3. Posadas-Calleja JG, Stelfox HT, Ferland A, Zuege DJ, Niven DJ, Berthiaume L, Doig CJ. Derivation of a PIRO Score for Prediction of Mortality in Surgical Patients With IntraAbdominal Sepsis. Am J Crit Care. 2018; 27(4): 287-294.

4. Rhodes A, Evans LE, Alhazzani W, Levy MM, Antonelli M, Ferrer R, et al. Surviving Sepsis Campaign: international guidelines for management of sepsis and septic shock: 2016. Intensive Care Med. 2017; 43(3): 304-77.

5. Sartelli M, Griffiths E, Nestori M. The challenge of post-operative peritonitis after gastrointestinal surgery. Updates in Surgery. 2015; 67(4): 373-381.

6. Scriba MF, Laing GL, Bruce JL, Clarke DL. The absolute number of repeat operations for complex intra-abdominal sepsis is not a useful predictor of non-survival. S Afr $\mathbf{J}$ Surg. 2017; 55(2):32-35.

7. Tokunaga M, Tanizawa Y, Bando E, et al. Poor survival rate in patients with postoperative intra-abdominal infectious complications following curative gastrectomy for gastric cancer. Annals of Surgical Oncology. 2013; 20: 1575-1583.

8. Torer N, Yorganci K, Elker D, Sayek I. Prognostic factors of the mortality of postoperative intraabdominal infections. Infection. 2010; 38(4):255-260

9. Wang HH, Huang CH, Kuo MC, Lin SY, Hsu CH, Lee CY, et al. Microbiology of peritoneal dialysis-related infection and factors of refractory peritoneal dialysis related peritonitis: A ten-year single-center study in Taiwan. Journal of microbiology immunology and infection. 2019; 52(5): 752-759. 